\title{
Lend-Lease in Early Post-war Soviet-American Relations
}

\author{
K. V.Minkova
}

For citation: Minkova K. V. Lend-Lease in Early Post-war Soviet-American Relations. Vestnik of Saint Petersburg University. History, 2018, vol. 63, issue 2, pp. 614-635. https://doi.org/10.21638/11701/ spbu02.2018.217

The article focuses on the early history of post-war Lend-Lease settlement between the U.S.S.R. and the U.S.A. It considers the political aspects of the establishment of the $\mathrm{Mu}-$ tual Aid program for the Soviet Union, the attitude of U.S. President F. D. Roosevelt and his administration, representatives of the U.S. Congress and the American people. The author uncovers the reasons and circumstances of the signing by U.S. President Harry Truman a note on the termination of Lend-Lease deliveries dated May 12, 1945. The author emphasizes that this note did not reflect Truman's personal attitude to the U.S.S. R. and was not directed solely against the Soviet Union. In addition, the author insists that the Soviet side was informed and repeatedly warned of the termination of deliveries after the end of hostilities in Europe well in advance. Thus, while acknowledging the imprudence and undiplomatic actions of the American side, one should not nevertheless accuse them of neglecting their duties, which they fulfilled in full. The article also uncovers the negotiations on Lend-Lease settlement in 1946, which have hardly been ever described in Soviet and Russian historiography. The intention to bind Lend-Lease settlement with other important economic problems in Soviet-American relations and, indirectly, to the participation of the U.S.S. R. in a number of important international trade and economic institutions - the IMF, the IBRD, the ITO - expressed by Washington in early 1946 has become an insurmountable obstacle to reaching a consensus between the parties and, as a result, has become one of the origins of the Cold war. However, one can not but acknowledge that an essential part of the blame for the failure of the 1945-1947 talks lies also on the Soviet leadership.

Keywords: Lend-Lease, Soviet-American relations, U.S.S.R., U.S.A., Mutual Aid program, credit, Roosevelt, Truman, Harriman.

\section{Ленд-лиз в советско-американских отношениях первых послевоенных лет}

\section{К. В. Минкова}

Для цитирования: Minkova K. V. Lend-Lease in Early Post-war Soviet-American Relations // Becтник Санкт-Петербургского университета. История. 2018. Т. 63. Вып. 2. С. 614-635. https://doi. org/10.21638/11701/spbu02.2018.217

Статья посвящена малоизученному в отечественной историографии вопросу об урегулировании расчетов по ленд-лизовским поставкам между СССР и США в 1945-1947 гг. Подробно рассматриваются политические аспекты становления программы взаимо-

Kristina V. Minkova - PhD in History, Senior Lecturer, St. Petersburg State University, 7-9, Universitetskaia nab., St. Petersburg, 199034, Russian Federation; k.minkova@spbu.ru

Кристина Владимировна Минкова - канд. ист. наук, старший преподаватель, Санкт-Петербургский государственный университет, Российская Федерация, 191060, Санкт-Петербург, Университетская наб., 7-9; k.minkova@spbu.ru

(C) Санкт-Петербургский государственный университет, 2018 
помощи, отношение к ней президента США Ф.Д.Рузвельта, чиновников его администрации, представителей Конгресса США и американского народа - на примере результатов соответствующих опросов общественного мнения. Вскрываются причины и обстоятельства подписания 12 мая 1945 г. президентом США Г. Трумэном ноты о прекращении поставок по ленд-лизу. Основываясь на нескольких документальных источниках, автор подчеркивает, что нота не отражала личного отношения Трумэна к СССР и не была направлена исключительно против Советского Союза. Кроме того, подтверждая свою аргументацию соответствующими источниками, автор настаивает на том, что советская сторона была заблаговременно и неоднократно предупреждена о прекращении поставок после окончания военных действий в Европе. Так образом, признавая неосторожность и недипломатичность действий американской стороны, не следует все же обвинять ее в пренебрежении своими обязанностями, которые выполнялись в полном объеме. В статье раскрываются также совершенно не представленные в советской и российской историографии переговоры по ленд-лизу в 1946 г. Привязка Вашингтоном урегулирования расчетов по ленд-лизу к решению других важных экономических проблем в советско-американских отношениях и, опосредованно, к участию СССР в выработке принципов функционирования ряда важнейших международных торгово-экономических институтов - МВФ, МБРР, МТО - стала непреодолимым препятствием на пути к достижению согласия между сторонами и в результате оказалась одной из причин начала "холодной войны». Впрочем, нельзя не признать и того, что существенная часть вины за провал переговоров 1945-1947 гг. лежит и на советском руководстве.

Ключевые слова: ленд-лиз, советско-американские отношения, СССР, США, программа взаимопомощи, кредит, Рузвельт, Трумэн, Гарриман.

Lend-Lease occupies an important place in the history of Soviet-American relations in the 1940s. It has been and still is a popular topic of research of Russian and foreign scholars ${ }^{1}$. Their works are mostly devoted to the economic significance of Lend-Lease for the victory of the Soviet Union in the Great Patriotic / Second World War. However, its political side still remains largely unexplored, existing within the framework of decades-old false stereotypes. In particular, the national historiography affirms that since 1942 the Lend-Lease supplies had been unconditionally supported by the U.S. population; that the order for the immediate cessation of Lend-Lease supplies, given by President G. Truman on May 12, 1945, was directed against the U.S.S.R. and became a complete

${ }^{1}$ Dunaeva N. Lend-liz: fakty i vymysly // Voenno-istoricheskii zhurnal. 1977. N 3. P. 102-106; Korotkov G.I. Lend-liz: mify I real'nost'// SShA: ekonomika, politika, ideologiia. 1985. N 6. P.47-53; Zorin L. I. Osoboe zadanie. Moscow, 1987; Chuzavkov L. M. Voenno-ekonomicheskoe sotrudnichestvo SSSR s SShA i Velikobritaniei v gody II mirovoi voiny. Moscow, 1972; Pozdeeva L. V. Lend-liz dlya SSSR: diskussiia prodolzhaetsia // Vtoraia mirovaia voinna. Aktual'nye problemy / ed. by O. A. Rzeshevskii. Moscow, 1995. P. 324-339; Suprun M. N. Prodovol'stvennye postavki v SSSR po lend-lizu v gody II mirovoi voiny // Otechestvennaia istoriia. 1996. N 3. P. 46-54; Lend-Liz i Rossiia / ed. by M. N. Suprun. Arkhangelsk, 2006; Butenina N. V. LendLiz: sdelka veka. Moscow, 2004; Sokolov V. B. Rol' lend-liza v Velikoŭ otechestvennoi voine 1941-1945 gg. // Stettinius E. Zagadki lend-liza. Moscow, 2000. P.305-332; Sokolov B. V. Diplomatiia i lend-liz // Ibid. P.333-348; Lugovskoı̆ S., Remizova S. Lend-liz: istoriia i sovremennost'// Ibid. P.349-397; Krasnov V.N., Krasnov I. V. Lend-liz dlya SSSR, 1941-1945. Moscow, 2008; Kravtsova Zh. V., Buriak I.I. Voenno-ekonomicheskoe sotrudnichestvo stran antigitlerovskoŭ koalitsii v 1941-1945 gg.: istoriia i sovremennye otsenki. Krasnodar, 2015; Komarkov A. Yu. Lend-liz dlia SSSR v pervyi god Velikoi Otechestvennoi: osobennosti, problemy, itogi // Obshchestvo, sreda, razvitie (Terra Humana). 2012. N 1. P.74-78; Golovatina P. M., Kamynin V.D. Anglo-amerikanskaia pomoshch' Sovetskomu Soyuzu po lend-lizu: vzgliad zarubezhnoĭ istoriografii // Ural'skii vestnik mezhdunarodnykh issledovanii. 2005. Iss. IV. P. 19-29. 
surprise to the Soviet leadership, etc. The Soviet-American dialogue on final settlement of Lend-Lease in 1946-1947, immediately after the signing of the Agreement of October 15,1945 , is rarely touched upon by the Russian historians. The present article is aimed at refuting the established clichés, filling in some lacunae in the national historiography of Lend-Lease, as well as bringing in some new data.

In the first months following the Nazi invasion of the Soviet Union, the question of including Moscow in the Lend-Lease program designed for the Allies of the United States was only discussed in the immediate surroundings of President F. D. Roosevelt. The overwhelming majority of Americans representing various social and religious groups were opposed to the U.S.S.R. These sentiments were eagerly supported by mass media. For example, the New York Journal American wrote at the beginning of September 1941: "If we are fighting against totalitarianism as a foul and oppressive policy, why in the name of high heaven should we not desire to see the two totalitarian powers exterminate each other and destroy not only the principle but the practice of despotic government?" 2 . This view was shared by other newspapers.

Literally from the very beginning of the Nazi aggression against the Soviet Union F. D. Roosevelt saw a change in public opinion in the United States as one of his most important tasks. He wanted to freely extend to the U.S.S.R. the program of Lend-Lease adopted by the Congress to assist the Allied Nations in March 1941. For this purpose, an active work was carried out in three directions:

1. As early as June 23, 1941, those leading newspapers of the United States that Roosevelt could win over ("The New York Times" and "The Washington Post" in the first place) began to feature the assistance to the U.S.S.R. as settled matter, requiring only specification of terms, methods and prospects ${ }^{3}$. However, they were, at least in the early going, strongly opposed by the isolationist press led by "Chicago Tribune". Having drawn its pen against the very idea of Lend-Lease in early 1941, its editor Robert McCormick refused to use the term "Lend-Lease" and referred instead to "the War Dictatorship Bill" in all its editorials, columns, and news stories". Later on he warned that "the Red Ally of today might turn to the Red Terror of tomorrow" . McCormick ideas were closely followed by "Time" which compared Hitlerite Germany and Stalinist Soviet Union with "vast prehistoric monsters lifting themselves out of the swamp, half-blind and savage" that "tore at each other's throats" 6 .

2. The Catholics, who constituted a significant part of the U.S. population and who were mostly anti-communist, were supposed to be influenced by a special declaration of

2 Langer W. L., Gleason S. E. The Undeclared War, 1940-1941. New York, 1953. P. 792.

3 The Government is for Any One Who Fights Hitler // The New York Times. 1941. June 24. P. 18; America, Committed to Help, Wonders if Reds Can Hold Out: U.S. May Aid Russia as 'Lesser Evil' // The Washington Post. 1941. June 24. P. 1; Reds Here Urge Lend-Lease Aid // The New York Times. 1941. June 25. P. 7; Treasury Frees Frozen Funds As First Step Of Cooperation: Initial U.S. Effort U. S. Pledges Soviet Aid, Frees Funds // The Washington Post. 1941. June 25. P. 1; Obstacles in the Way of Our Aid to Russia // The New York Times. 1941. June 29. P.E3; Soviet Requests U. S. Help; Offers to Pay for Supplies // The New York Times. 1941. July 2. P. 1.

${ }^{4}$ Olson L. Those Angry Days: Roosevelt, Lindbergh, and America's Fight Over World War II, 19391941. New York, 2014, p. 278.

5 Sirgiovanni G. An Undercurrent of Suspicion: Anti-communism in America during World War II. New Brunswick, 1990. P. 36.

${ }^{6}$ Chicago Tribune. July 30, 1941. 
Pope Pius XI, interpreting the encyclical Divini Redemptoris of $1937^{7}$ opposed to communism, in a manner favorable to the Soviet leadership. It is for these purposes that a special emissary of Roosevelt Myron Taylor was sent to the Vatican, and his mission was successful ${ }^{8}$. Here the President was opposed by a number of Catholic newspapers and magazines including "Catholic Beacon", "Catholic Register", and "Catholic World". The latter dubbed Lend-Lease assistance to the U.S.S. R. "a covenant with hell"'.

3. Secret negotiations were held with the Soviet ambassador to the U.S. K. Umansky about the possibility of delivering American weapons and equipment in exchange for gold until the Act on Lend-Lease would be extended to the Soviet Union.

Roosevelt's policy turned out to be quite successful. On October 4, 1941, following the talks between the members of the American delegation and the Soviet leadership during the Moscow conference on September 29 - October 1, 1941, the Soviet Information Office (Informbureau) issued a statement on freedom of religion in the U.S.S.R. This news was immediately picked up by the American central newspapers ${ }^{10}$.

On October 10, the House of Representatives, voting for the second draft of the LendLease, rejected by 217 votes to 162 the amendment banning the use of these funds to aid the Soviet Union ${ }^{11}$. On October 23, the same vote took place in the Senate, where the bill was adopted by 59 votes to $13^{12}$. At that, no single opinion on the extension of Lend-Lease to the U.S.S. R. was achieved even in the ranks of Roosevelt's party - the Democrats. For example, Senator C. Pepper claimed: "If we don't spend \$5,000,000,000 or so to stop Hitler in Europe now, it will cost us 5 to 20 times 5,000,000,000 to stop him later". His colleague, Senator Byrd, insisted that "this country is not producing enough military equipment for its own needs and those of Great Britain"13.

By November 6, in a number of telegrams Stalin and Roosevelt had settled all formalities regarding the terms of delivery, and on November 7, 1941, the Soviet Union officially entered the American Lend-Lease program on the same rights and principles as the United Kingdom and China ${ }^{14}$.

It should be emphasized that until that moment, Moscow had paid in cash for those rare supplies of machinery and equipment that the United States and Great Britain were able to provide to the U.S.S.R. According to E. Stettinius, who directed the entire LendLease program in 1941 - early 1945, from June 23 to November 7, 1941, Amtorg ${ }^{15}$ paid the U.S. $\$ 92 \mathrm{mln}^{16}$.

7 Papal Encyclical Divini Redemptoris. URL: https://w2.vatican.va/content/pius-xi/en/encyclicals/ documents/hf_p-xi_enc_19370319_divini-redemptoris.html (accessed 16.01.2018)

${ }^{8}$ Memorandum from Mr. President to Mr. Taylor. September 1, 1941. Roosevelt's Papers. The Secretary's File. Box 76.

${ }_{9}$ Gillis J. Covenant with Hell // Catholic World. 1941. August 1941. P. 513-517.

10 Religious Freedom in the Soviet Union // The New York Times. 1941. October 6. P. 16.

11 Langer W. L., Gleason S. E. The Undeclared War, 1940-1941. P. 818.

12 Outstanding Roll Calls in the Senate, 1941. URL: http://library.cqpress.com/cqresearcher/document.php?id=cqresrre19411215votes00 (accessed 16.01.2018)

13 Senate Survey on Aid to Russia Discloses Fear U.S. May Be Called On for More // The Washington Post. 1941. June 29. P. 4.

14 Stettinius E. Lend-liz - oruzhie pobedy // Stettinius E. Zagadki lend-liza. Moscow, 2000. P.130132.

15 Amtorg is a Soviet-American joint stock company founded in 1924 to act as an intermediary in export-import operations of Soviet foreign trade associations with US companies.

16 Stettinius E. Lend-liz - oruzhie pobedy... P. 129. 
The measures taken by F. D. Roosevelt to change public opinion in the U.S. in favor of rendering the greatest possible assistance to the Soviet Union proved to be successful only on a formal level. While the Congressmen's opinion had changed so much that it allowed the Administration to successfully navigate the relevant bills through the Congress, the president could not significantly change the mood of the commons. This is evidenced by the results of numerous public opinion polls conducted in the United States in 19411945 not only by the Gallup Institute, but also by other sociological services (AIPO American Institute of Public Opinion, NORC - National Opinion Research Center etc.).

Thus, on June 24, 1941, the question of whether the U.S. should supply U.S. S. R with weapons, aircraft and other war resources on the same conditions as Great Britain, only $35 \%$ answered in the affirmative (with $54 \%$ in the negative) ${ }^{17}$. On August 5, when asked whether the U.S.S.R. should be included in the Lend-Lease program, $38 \%$ of respondents replied in the positive and $39 \%$ - in the negative ${ }^{18}$. It should be pointed out that at the same time $74 \%$ of the polled supported the American aid to the few troops of Free France (against $16 \%)^{19}$.

On January 16, 1942, when asked whether the United States should send as much resources to Russia as possible to wage war, 26 percent of the polled voted positively and 66 percent were in the negative ${ }^{20}$. In February of the same year, 75, 63 and $76 \%$, respectively, responded positively to the question whether the U.K., China and Russia should pay the U.S. for Lend-Lease supplies ${ }^{21}$. Thus, the attitude towards their old ally, Britain, and their old antagonist, the Soviet Union, among the Americans was about the same and somewhat more negative (italics added. - K.M.) than to China! These sentiments did not change much in the course of further interviews in July, October and November 1942. At the same time, the overwhelming majority of respondents favored continuation of supplies to the Allies even if this would lead to a deficit of food or industrial goods in the United States itself (88\% in September 1942 and $94 \%$ in January 1943) ${ }^{22}$.

By August 1943, the situation got a new, rather ambiguous development. On the one hand, the military efforts of the Allies (and, first of all, of the Soviet Union) were finally recognized by the American people. To the traditional question whether the Allies' efforts were a sufficient payment for Lend-Lease supplies, $51 \%$ of respondents answered in favor of Russia (compared to $36 \%$ for full or at least partial payment for American supplies), and $42 \%$ against the United Kingdom ( $45 \%$ of those polled answered in the negative) ${ }^{23}$. In October 1943, $79 \%$ of respondents believed that the United Kingdom should fully or partially pay for the received Lend-Lease supplies, and in September 1945 their number increased to $83 \%^{24}$.

On the other hand, a poll by the Gallup Institute in July 1943 showed that $55 \%$ of Americans believed that it was the U.S. that made a decisive contribution (italics added K.M.) to the war against Germany. $32 \%$ of respondents voted for the U.S.S.R. with $9 \%$

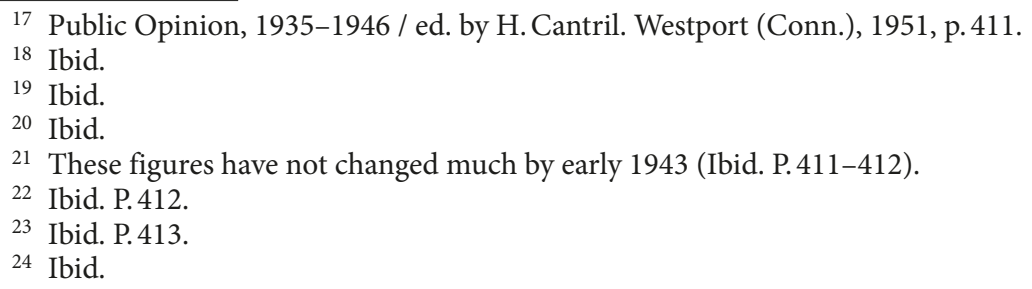


and $4 \%$ for Britain and China ${ }^{25}$. The quality and representativeness of these surveys is beyond doubt. The issue is the awareness of American citizens of the development of military operations and the Allies' contribution to them: it is known that in January $194323 \%$ of respondents had no idea about Lend-Lease at all ${ }^{26}$.

Be that as it may, these sentiments, which began to be felt in the country, the shortage of food and industrial goods (meat, clothing, petrol), as well as growing confidence in the unconditional victory of the Allies, could not but affect the stance of Congressmen and the business elite on a number of key aspects of domestic and foreign policy of the United States closely related to Lend-Lease.

In 1944-1945, many American business leaders became more active not only against allocating huge funds for military aid to the Allies, but also against the active intervention of the state in the economy and foreign trade. The global reorientation of American industry to produce goods and equipment most in demand by the Allies caused great concern (in $1941,22 \%$ of U.S. industrial output went to war; in 1942, it increased to $55 \%$ ) $^{27}$.

In 1944 and 1945, the U.S. Congress prolonged the Lend-Lease Act, but every year the opposition gained ever more votes. It is noteworthy that in February 1945, its fate in the Senate was decided by a tie vote - and it was then-vice-president of the United States, Harry Truman, who broke the tie ${ }^{28}$. It should be noted that even this political constellation in the Congress became possible only after the repeated guarantees on the cessation of supply after the end of hostilities in Europe given by Roosevelt and his Administration. Congressmen (including a well-known politician and future Chairman of the U.S. Senate Committee on Foreign Relations Arthur H. Vandenberg) insisted that the LendLease program should not extend "one minute or one dollar in the post-war period". It is extremely important to emphasize that it was about supporting all the Allies, including Great Britain. Public opinion in 1945 was presuming that the Allies should pay for the products, materials, equipment and weapons supplied by Lend-Lease: $65 \%$ of Americans spoke for it, according to the results of a survey conducted in April and July $1945^{29}$.

These sentiments in the commons and in the Congress were fueled by a variety of rumors and fears that first arose in the summer of 1944. For instance, in early August, "The New York Times" featured that the British were asking to extend the Lend-Lease for the post-war period ${ }^{30}$. In November 1944, it was reported that during the Second Quebec Conference, Roosevelt and Churchill agreed on the supply of U.S. goods to the United Kingdom by $\$ 6$ billion after the defeat of Germany ${ }^{31}$. In March 1945, there were rumors about the intention of Great Britain and the U.S.S.R. to ask the U.S. for financial aid after the war ended ${ }^{32}$. Interestingly, the Americans gave exactly the same answers to the relevant questions asked at the end of October 1945 regarding both countries: $60 \%$ of

25 The Gallup Poll: Public Opinion, 1935-1971. In 3 vols. Vol. I. New York, 1972. P. 394.

26 The Gallup Poll... P. 366. According to another source, completely ignorant of the idea of lend-lease were $27 \%$ of respondents (Public Opinion, 1935-1946... P. 412).

27 Dalin S. Voenno-gosudarstvennyı̌ monopolisticheskiĭ kapitalizm v SShA. Moscow, 1961. P. 280.

28 Congressional Record. $79^{\text {th }}$ Congress. 1 Session. 1945. April 10. P. 3232-3254.

29 Public Opinion, 1935-1946... P. 414.

30 Urge Lend-Lease to Britain Continue After Reich Falls: New Lend-Lease Urged for Britain // The New York Times. 1944. August 7. P. 1.

31 British Ask More on Lease With the Right of Resale // The New York Times. 1944. November 3. P. 1,6 .

${ }^{32}$ Loan Rumors Raised by Wolcott at Hearing on World Fund Bill // The New York Times. 1945. March 17. P. 10. 
respondents expressed a categorical opposition to the granting of credit both to the Soviet Union and Britain. That said, it is beyond doubt that the images of these two countries in the public opinion of the United States in that period could not have been the same.

Meanwhile, the position of F. D. Roosevelt and his supporters in the U.S. administration regarding the supply of materials, goods and equipment to the U.S.S.R. remained extremely favorable of the Soviet Union until Roosevelt's death.

To begin with, it should be remembered that the Soviet Union occupied a truly unique place among all the recipients of Lend-Lease aid. President Roosevelt not only considered the U.S.S.R. the top priority recipient of the American aid, but personally supervised it via an ad hoc committee (President's Soviet Protocol Committee) headed by his authorized representative Harry L. Hopkins $s^{33}$. While other recipients were required to provide irrefutable evidence of their need of the materials, equipment, food and industrial goods they requested, and proof of their use for military purposes, Soviet demands were accepted unconditionally ${ }^{34}$. If the lists submitted by other recipients were constantly updated to reduce the amount and scope of assistance, then the requests of the Soviet Union were not only fulfilled in full from the early 1942, but sometimes they were even overfulfilled. For example, in the framework of the Third Protocol (mid-1943 - mid-1944), shipments to the U.S.S.R. exceeded planned volumes by $30 \%^{35}$. After the opening of the second front and the improvement of the general situation on the fronts, aid to most countries, but not to the U.S.S.R., was significantly curtailed ${ }^{36}$.

It is noteworthy that even in the early stages of Lend-Lease, some officials from Roosevelt's team tried to persuade him to limit the U.S. aid to Moscow (at least by those positions that directly strengthened the military power of the U.S.S.R. - e.g. by aircraft) or to provide this assistance on a reciprocal basis - i.e. in exchange for gold, strategic metals, etc. Admiral W. Standley, who preceded W. Averell Harriman as U.S. Ambassador to the U.S.S.R., kept warning Roosevelt that the Soviet leadership was taking advantage of his generosity ${ }^{37}$.

These attempts gained strength in 1944, after Washington learned that the equipment received by the U.S.S.R. on the terms of Lend-Lease was often misused, stood idle or simply disappeared ${ }^{38}$. In addition, the lists of orders submitted by the Soviet side clearly showed that some items were originally intended for use after the end of the war. Moreover, Roosevelt's team was deeply affected by the news that Moscow had been transferring or reselling to third countries either goods and equipment obtained through Lend-Lease, or their counterparts in order to strengthen its political influence in Eastern Europe and the Middle East. Thus, sugar and tires were sold to Iranians; trucks were sold or donated to Poland etc. ${ }^{39}$ This problem looms large in the documents of U.S. foreign policy dated

${ }^{33}$ Herring G. C., Jr. Experiment in Foreign Aid: Lend-Lease, 1941-1945. PhD Diss., University of Virginia, 1965. P. 232-78.

${ }^{34}$ Martel L. Lend-Lease, Loans and the Coming of the Cold War: A Study of the Implementation of Foreign Policy. Boulder (Col.), 1979. P. 144.

35 "Narkomvneshtorg schitaet tselesoobraznym organizovat' zakupochnuyu komissiiu". Istoriia lend-liza v dokumentakh RGAE. Fevral' 1942 - mart 1945 g. // Istoricheskii arkhiv. 2013. N 5. P.31-55.

${ }^{36}$ Report on War Aid Furnished by the United States to the U.S. S. R. Washington, 1945.

37 Standley W. H., Ageton A. Admiral Ambassador to Russia. Chicago, 1955. P. 239.

38 Deane J.R. The Strange Alliance: The Story of Our Efforts at Wartime Co-operation with Russia. New York, 194. P.96-97.

39 State Department Decimal Files 861.24/6-544, 5 June 1944. 
July-December $1944^{40}$. For instance, on July 6, 1944, a corresponding request was sent to the Soviet Embassy in Washington - and for a long time remained unanswered ${ }^{41}$. On December 19, 1944, the Ambassador of the U.S. S. R. in the United States Andrey Gromyko was given a respective note of protest ${ }^{42}$. In response, the Soviet leadership indicated that the Lend-Lease Agreement did not contain provisions that prevented exports of goods and equipment similar to those obtained through Lend-Lease to other countries, but expressed readiness to continue consultations with representatives of the U.S. government on this issue ${ }^{43}$.

Roosevelt was convinced that by providing generous assistance to the Soviet Union, he was laying a solid foundation for friendly relations between the U.S.S.R. and the U.S. in the postwar years ${ }^{44}$. However, throughout 1944, his advisers (primarily, A. Harriman and the Chief of the U.S. Military Mission in Moscow, Major General John R.Deane) repeatedly warned him that the generosity of the American government could be interpreted by the Soviet leadership as a sign of its weakness ${ }^{45}$. Harriman, Deane and U.S. Secretary of the Navy Frank Knox insisted that the Soviet side should be obliged to review its requests and make some concessions in exchange for provided assistance (for example, to improve the quality of communications and exchange with U.S. military intelligence data and information about weather conditions). In addition, Harriman believed that LendLease could be used as a lever of pressure on the Kremlin in order to protect U.S. interests in Eastern Europe ${ }^{46}$.

However, Roosevelt had been insisting on keeping unchanged the volumes of LendLease supplies to the Soviet Union practically to his death, even if realizing that his plan to establish friendly relations with the U.S.S.R. as the guarantor of a future peace on the planet was failing ${ }^{47}$. With regard to Eastern Europe, he believed that the U.S.S.R. was the dominant power in that region, and the U.S.A. should not interfere in its relations with those countries. A similar position was held by a very influential American diplomat George F. Kennan, who worked for many years at the U. S. Embassy in Moscow. In a letter to Charles E. Bohlen, expert of the State Department and future adviser to H. Truman, which reached him in early February 1945 at the Yalta Conference, Kennan wrote, in particular:

40 The Ambassador in the Soviet Union to the Secretary of State. September 7, 1944 // Foreign Relations of the United States (FRUS). 1944. Vol. IV. P. 1131; The Secretary of State to the Ambassador of the Soviet Union. September 16, 1944 // Ibid. P. 1135; The Ambassador in the Soviet Union to the Secretary of State. September 22, 1944 // Ibid. P. 1148.

41 The Department of State to the Embassy of the Soviet Union. July 6, 1944 // Ibid. P. 1098-1099.

42 The Secretary of State to the Ambassador of the Soviet Union. December 19, 1944 // Ibid. P. 11571158.

43 Proekt otveta Gosudarstvennomu departamentu SShA na notu, vruchennuiu Achesonom tov. Gromyko 20 dekabria 1944 g. // Arkhiv vneshneĭ politiki Rossiǐskoŭ Federatsii (AVPRF). F.06. Op.6. P. 46. D. 624. L. 24.

44 See: Blum J.M. From the Morgenthau Diaries: in 3 vols. Vol.III. Boston, 1967. P. 80-87; Dawson R. H. The Decision to Aid Russia, 1941: Foreign Policy and Domestic Politics. Chapel Hill, 1959.

45 The Ambassador in the Soviet Union (Harriman) to Mr. Harry L. Hopkins, Special Assistant to President Roosevelt. September 10, 1944 // FRUS. 1944. Vol. IV. P. 988-990.

46 The Ambassador in the Soviet Union (Harriman) to the Secretary of State. March 13, 1944 // FRUS. 1944. Vol. IV. P. 951.

${ }^{47}$ Herring G. C. Lend-Lease to Russia and the Origins of the Cold War, 1944-1945 // The Journal of American History. 1969. Vol. 56, N 1. P. 98. 
"I am aware of the realities of this war, and of the fact that we were too weak to win it without Russian cooperation. I recognize that Russia's war effort has been masterful and effective and must, to a certain extent, find its reward at the expense of other peoples in eastern and central Europe.

$\langle\ldots\rangle$ Why could not we make a decent and definitive compromise with it - divide Europe frankly into spheres of influence - keep ourselves out of the Russian sphere and keep the Russians out of ours? That would have been the best thing we could do for ourselves and for our friends and Europe, and the most honest approach we could have tried to restore life, in the wake of war, on a dignified and stable foundation" ${ }^{\text {"48. }}$.

Both Roosevelt and his Secretary of State Cordell Hull were well aware that there was no sense in "bargaining" with Moscow at the end of the war as the Soviet Union was able to win it even under condition of the complete cessation of supplies of American weapons, food and manufactured goods.

In order to maintain and strengthen relations with the Soviet leadership, Roosevelt approved a supply plan on terms of credit to fill the possible gap between the end of LendLease aid and the start of the post-war assistance program for the U.S.S.R. This plan was based on section 3 (c) of the Lend-Lease Act of 1943 and, accordingly, was entitled a “3 (C) Agreement”. It allowed the Soviet government to place large orders for industrial equipment in the United States, even if it was not required for military operations or could not be used until the end of the war. All deliveries before the announcement of the end of hostilities had to go along the Lend-Lease line, and afterwards - on terms of credit ${ }^{49}$.

It should be emphasized that the 3 (C) Agreement, later extended to other states, was originally designed for the Soviet Union and can serve as a dramatic proof of the importance that President Roosevelt attributed to the post-war assistance of the U.S.S. R. as an instrument for maintaining Soviet-American friendship. Despite the American researchers arguing the opposite $e^{50}$, the termination of negotiations on this Agreement on March 24, 1945, is the most important evidence of the change in Roosevelt's attitude to the Soviet leadership and personally to Stalin. It was at this time that first visible tension arose between the two leaders. It was caused both by objective reasons (antipodal views on the problems of the postwar world order, different interpretations of the same events and facts, Soviet policy in Eastern Europe), and by some steps undertaken by Harriman, who adopted openly anti-Soviet position in the early autumn of $1944^{51}$. The formal reason for the termination of the negotiations was the reluctance of the Soviet side to accept the financial terms of the loan offered by the Americans. While Washington's offer was quite traditional for that period $(2-3 \%$ per annum and payment from the end of the 5 th year), Moscow insisted on $0.5 \%$ per annum and payment starting from the 16 th year ${ }^{52}$. Rejecting the American proposal, the Soviet leadership apparently hoped to achieve some concessions, since it was already accustomed to the fact that until that point almost all disputable issues in bilateral relations had been resolved in its favor. However, in that case Roosevelt and Hull did not make any advances towards the Kremlin. In early 1945, the President first recognized the existence of problems in relations with the Soviet Union:

48 Bohlen C. E. Witness to History, 1929-1969. New York, 1973. P. 175.

49 See e.g.: The Acting Secretary of State to the Ambassador in the Soviet Union (Harriman). March 7, 1944 // FRUS. 1944. Vol. IV.P. 1060-1062.

50 See e.g.: Martel L. Lend-Lease, Loans and the Coming of the Cold War. P. 119.

${ }^{51}$ Harriman W.A. America and Russia in a Changing World. Garden City, 1971. P. 43.

52 The Ambassador in the Soviet Union to the Secretary of State. March 23, 1944 // FRUS. 1944. Vol. IV. P. 1069-1070. 
"The nearer we come to vanquishing our enemies, the more we inevitably become clear of differences among the victors" ${ }^{3}$. Hull was sharing his fears: "In dealing with the Soviet Union, we must never... give any evidence of weakness" 54 .

The U.S. administration did not insist on continuation of the 3 (C) Agreement negotiations for yet another reason: the Committee on Foreign Economic Assistance (FEA) believed that the signing of such an agreement shortly before the end of the war could be regarded by the Congress as an attempt to use Lend-Lease for post-war purposes. The head of the Committee, Leo Crowley, recommended Roosevelt to withdraw the draft Agreement, and the President agreed ${ }^{55}$.

Considering the plans of the postwar U.S. assistance to the Soviet Union, we should pay attention to yet another interesting fact. In mid-May 1944, Averell Harriman, who was then still sympathetic to the U.S.S.R., prepared a memorandum to President Roosevelt, where he insisted that "it is essential to explain our policy to the Russians during the war" as "any presentation of unanticipated claims afterwards would seriously threaten the continuance of good relations" ${ }^{56}$. Beside that, Harriman attempted to include in the text of the Fourth Protocol of Lend-Lease supplies to the U.S.S. R., covering the period from July 1944 to June 1945, a provision on changing its effect in the event of the fall of Germany. Roosevelt not only flatly refused to approve this provision, but also ordered to suspend any further planning: "It is my wish that no Department of the Government take unilateral action in regard to any matters that concern Lease Lend, because the implications of any such action are bound to affect other Departments of the Government and, indeed, our whole national policy" ${ }^{57}$. This reluctance (or inability) of Roosevelt to approve the program of post-war assistance to the Allies in advance led to grave consequences.

A few weeks after Roosevelt's death and the arrival of President Truman, the need to make changes to the program of economic assistance to the U.S.S.R. (and generally to all the Allies) became evident. Contrary to the opinion held in the national historiography, these changes were not related to the new President's personal attitude to the Soviet Union or its leader ${ }^{58}$. Only a few days left before the end of the hostilities in Europe, so it was necessary to urgently formulate the basic principles of Soviet-American economic cooperation after the V-E Day. Before providing a detailed description of the events that preceded the famous note of 12 May 1945 on the cessation of Lend-Lease supplies to the U.S.S.R, we should focus on the following critical points that partly remove the blame for the diplomatic conflict, provoked by this note, from $\mathrm{H}$. Truman. Firstly, in making any decisions concerning the Soviet Union, the new President listened to the opinion of A.Harriman, who, as we mentioned earlier, in the fall of 1944 changed his attitude to the U.S.S.R. from moderately positive to generally negative. Secondly, when making decisions in the economic sphere, the President consulted with the head of the FEA Leo Crowley, who had never been a great proponent of the Soviet Union either. Thirdly, Truman was afraid

${ }^{53}$ Byrnes J.F. Speaking Frankly. New York, 1947. P. 60.

54 The Memoirs of Cordell Hull. New York, 1948. P. 1740.

55 Memorandum by the Acting Secretary of State and the Foreign Economic Administrator (Crowley) to President Roosevelt. March 23, 1945 // FRUS. 1945. Vol. V. P. 991.

${ }^{56}$ Memorandum for the President by the Ambassador to the Soviet Union (Harriman). Prepared on May 19, 1944 // FRUS. 1944. Vol. IV. P. 1084.

57 The President to the Secretary of State. September 9, 1944. URL: https://history.state.gov/historicaldocuments/frus1944Quebec/d112 (accessed 16.01.2018)

58 Stepanova O. L. «Kholodnaia voinna»: istoricheskaia retrospektiva. Moscow, 1982. P. 20. 
of the Congress with its constantly growing isolationist sentiments which by the end of the war had reached their climax. Finally, a May 12 note was drawn up only a month after Roosevelt's death. Obviously, Truman, who was not actually allowed to participate in shaping the U.S. foreign policy as a vice-president, could not become completely aware of the constantly changing political situation in such a short time.

Harriman was persistent that cooperation with the Soviet side should be placed on a "realistic basis"; that a firm position should be developed in her respect and that her actions are "intolerable and can not continue" 59 . In addition, he advocated reorienting the U.S. foreign economic policy towards the Western allies and other regions that were "under their responsibility", and allocating to Russia "what may be left" ${ }^{60}$. Harriman laid out his views to Roosevelt a few days before his death and, of course, did not change them when making recommendations for Truman.

The new President stood in full solidarity with Harriman: "The only way to establish sound relations between Russia and ourselves", he wrote on April 20, was "on a give-andtake basis"61. It should be noted that both politicians were confident that tightening economic policy towards the Soviet Union would not lead to a political rupture of bilateral relations due to the Soviet dependence on American supplies.

On April 23, 1945, the White House hosted a meeting of some members of the U.S. administration, who came to the conclusion that no damage will be caused to the Allied military forces and the general course of war if the Soviet troops reduced activity or ceased to operate in Europe at all. A more important problem was Japan, but even in that matter, the estimates of U.S. military analysts had changed significantly compared to the calculations that Roosevelt obtained while preparing for the Yalta Conference in late January 1945. The entry of the Soviet Union into the war with Japan was no longer vitally necessary for its successful outcome. Although General George C. Marshall, the Chief of Staff of the United States Army, and a Secretary of War Henry L. Stimson spoke out against Harriman and Deane and for the U.S.S.R. to join the war, as a result of the meeting, the participation of the Soviet Union in the war in the Far East was deemed desirable, but not mandatory. In addition, the officials agreed that the transition to a tougher policy towards the U.S.S.R. should not affect its decisions regarding participation or non-participation in hostilities, as it was supposed to be determined by Moscow's interests in Asia ${ }^{62}$.

It should be stressed had Roosevelt been alive, such a meeting would have taken place about the same time. Its necessity was dictated both by the need to adapt the home policy and economic policy to the realities of peace, and the termination of the Lend-Lease Act, which was in effect only during military operations.

On May 9, 1945, Harriman and U.S. Secretary of State Edward Stettinius, both members of the U.S. delegation at the San Francisco Conference, discussed the possible consequences of curtailment of Lend-Lease aid to the U.S.S.R. for successful negotiation of the UN Charter. At that point, the agenda of the conference had already left two major issues - Polish problem and procedural voting in the UN Security Council - unresolved.

59 The Ambassador in the Soviet Union (Harriman) to the Secretary of State. April 6, 1945 // FRUS. 1945. Vol. V. P. $822-823$.

60 The Ambassador in the Soviet Union (Harriman) to the Secretary of State. April 4, 1945 // Ibid. P. 817-820.

${ }^{61}$ Truman H. S. Memoirs: in 2 vols. Vol. I: The Year of Decisions. New York, 1955. P. 86.

${ }^{62}$ Memorandum by Mr. Charles E. Bohlen of a meeting at the White House. April 23, 1945 // FRUS. 1945. Vol. V. P. 252-255. 
Both politicians agreed that no acts of pressure or retaliation on the Soviet leadership should be suggested or considered until after the San Francisco Conference and, accordingly, the work on the UN Charter. Any adjustments to the Lend-Lease program were supposed to be conducted as tactfully as possible "without any hints at relations with Polish or other political problems with the Soviet Union"63. On the same day, Stettinius advised the State Department to take a firm approach toward the Soviets but to avoid "any implication of a threat or any signs of political bargaining" 64 .

On the following day, May 10, Harriman communicated with Truman on the amending the policy of Lend-Lease. Later that day Harriman gathered representatives of all Government agencies involved in the program of aid to the Soviet Union to discuss the text of the memorandum, which would clearly define the principles of the new policy, to be signed by the President ${ }^{65}$.

On May 11, the draft of this memorandum was ready. Having enlisted Harriman's support, the then Acting Secretary of State Joseph C. Grew and Leo Crowley presented it to Truman in the following phrasing:

"Deliveries of supplies under current Lend-Lease programs for the U.S.S.R. should be adjusted immediately to take account of the end of organized resistance in Europe. So long as it is anticipated that the U.S.S.R. will enter the war against Japan, it is proposed to continue deliveries under the program in the Annex III of the Fourth Protocol which includes military supplies, raw materials, industrial equipment and food to support Soviet military operations in the Pacific theater. Additional supplies now on hand or on order for the U.S.S.R would also be delivered to the extent that they are necessary to support such military operations. Supplies needed to complete industrial plants already partially made available under previous commitments should be delivered. Other Lend-Lease supplies programmed for the U.S.S.R. should be cut off immediately as far as physically practicable, and such goods and the related shipping tonnage should be diverted to the approved supply programs for Western Europe"66.

Descriptions of further developments are full of discrepancies. Grew claims that he and Crowley "wanted to be sure that the President thoroughly understands the situation". Crowley predicted the Kremlin's painful reaction and did not want the Russians to "be running all over town looking for help" ${ }^{27}$. Truman recalls that Grew and Crowley brought him for signing a document, which, according to them, President Roosevelt had approved but not signed. Since in U.S. political quarters the termination of Lend-Lease supplies after the end of hostilities was a settled thing, Truman signed the memorandum, practically without reading it. In his memoirs, he describes this event as his "first bad experience in the problem of delegating authority": "They [Grew and Crowley. - K.M.] asked me to sign it. I reached for my pen and, without reading the document, I signed it" ${ }^{68}$. Referring to documentary evidence, L. Martel argues that this memorandum owed an exceptionally

${ }^{63}$ The Diaries of Edward R. Stettinius Jr. / eds T. M. Campbell, G. C. Herring. New York, 1975. P. 357358.

64 The Secretary of State (Stettinius) to the Acting Secretary of State (Grew). May 9, 1945 // FRUS. 1945. Vol. V. P. 998.

${ }^{65}$ Herring G. C. Aid to Russia, 1941-1946. New York, 1973. P. 202-203.

${ }^{66}$ Memorandum by the Acting Secretary of State (Grew) and the Foreign Economic Administrator (Crowley) to President Truman. May 11, 1945 // FRUS. 1945. Vol. V. P. 999-1000.

67 Ibid. P. $999 \mathrm{ff}$.

68 Truman H.S. Memoirs. In 2 vols. Vol. 1. P. 255. - Truman indicated a wrong date of signing the memorandum - May 8. Ibid. P. 254. 
harsh tone to a "third party" - Elbridge Durbrow, the Chief of the Division of Eastern European Affairs of the State Department ${ }^{69}$.

Immediately afterwards, Truman approved of the following text of the note to the Soviet embassy, announcing the end of hostilities in Europe and the need to revise the Lend-Lease program in accordance with the new principles stated in the note:

"Deliveries of supplies under current Lend-Lease programs for the U.S.S. R. will be adjusted immediately to take account of the end of organized resistance in Europe $e^{70}$.

It is remarkable that both the Soviet leadership and the American bureaucratic apparatus took this phrasing as an instruction to the immediate cessation of all deliveries, although the text didn't impose such measures. On the contrary, the note began with assurances of the desire of the U.S. government "to continue to provide the Government of the Union of Soviet Socialist Republics with assistance in meeting its military needs for such supplies as required in the list of war conditions" ${ }^{\prime 1}$.

It should be emphasized that, formally, under the Lend-Lease Act, the United States could not continue to deliver supplies to a state that was not at war (in this case, with Japan $)^{72}$. Thus, for the U.S. leadership, even this wording presented a certain danger in terms of a possible confrontation of the Congress.

In the morning of May 12, 1945, a meeting of the Subcommittee on shipping of the President's Protocol Committee was held to implement the new order. The phrase stating that the supplies "should be cut off immediately as far as physically practicable" triggered an enormous controversy ${ }^{73}$. Finally, the debates were won by the officials of the Foreign Economic Administration who came down in favor of strict construction.

As a result, the loading of all ships that were to be sent to the Soviet Union and other Allied countries was suspended, and vessels already at sea were ordered to return to the United States.

Later Stettinius, who did not manage the Lend-Lease program after taking up the post of Secretary of State, recalled the events of May 12 as "untimely incredible move"74.

Harriman and Assistant Secretary of State William Clayton were shocked by its consequences ${ }^{75}$.

Both Soviet and American documents witness that the May 12 note led to a serious diplomatic blunder: the Soviet leadership got the impression that the new U.S. administration was trying to use Lend-Lease as a lever of pressure on the Kremlin. As we noted, it was exactly what Harriman attempted to avoid by all means.

69 Martel L. Lend-Lease... P. 130.

70 AVPRF. F. 6. Op. 7. P. 45. D. 702. L. 1; The Acting Secretary of State to the Chargé of the Soviet Union (Novikov). May 12, 1945 // FRUS. 1945. Vol. V. P. 1000-1001.

71 Ibid.

72 The Lend-Lease Act of 1941. URL: http://www.digitalhistory.uh.edu/disp_textbook.cfm?smtID=3\&psid=4075 (accessed 16.01.2018)

73 Minutes of meeting, Protocol Subcommittee on Shipping, May 12, 1945. Records of the Army Service Forces, Director of Materiél File. General Correspondence. General Edgerton's Lend-Lease File. Box 5. U.S.S.R. Folder.

74 Stettinius E. R. Roosevelt and the Russians: The Yalta Conference. Garden City, 1949. P. 318.

75 Herring G. C. Jr. Aid to Russia... P. 205. 
Truman tried to put all the blame on Grew and Crowley: "The sudden stoppage of Lend-Lease was clearly a case of policy-making on the part of Crowley and Grew"'", but, of course, the main fault rests with him.

However, a share of blame for the events of May 11-12, 1945, which led to diplomatic crises in U.S. relations both with the Soviet Union and Great Britain lies on Roosevelt, since he could not (and didn't even try) to convince the Congress of the need to continue economic aid to the countries of Europe and the U.S.S.R. after the end of hostilities. It must be stressed that President Roosevelt would also be forced to stop supplying allies with Lend-Lease, but with no doubt he would never have done it so rudely.

The American people reacted to the events of May 12 ambiguously: answering to a respective question, $49 \%$ of those polled claimed that Lend-Lease should have been stopped when it was and in the way it was, and $35 \%$ - that it should not have been done so suddenly or should have been extended up to a year ${ }^{77}$.

On May 28, 1945, Harry Hopkins, sent by Truman on a special mission to Moscow, met with Stalin to personally apologize for "technical misunderstanding by one government agency"78. That meeting was also designed to discuss the question of supplies needed by the Soviet Union to conduct the war in the Far East. Afterwards General J. Deane singled out of the presented list those positions that deemed the most important to him, and gave instructions for their immediate shipment even in the absence of confirmation of the validity of the claims. The U.S.S. R. requested 570 thousand tons, the War Department approved of procurement of 185 thousand tons, and prepared for shipment before the surrender of Japan was about half that ${ }^{79}$. This could be explained by several reasons. To begin with, the Soviet side, for the first time in the history of Lend-Lease, had to justify its requests - that is, to provide evidence that the required materials and equipment would actually be used in the Far East. Secondly, in the summer of 1945, the Joint Chiefs of Staff began to take an increasing influence on the President, opposing the provision of economic aid on a former basis both to the U.S.S. R. and Western Europe. Having been drawn over to opposite sides by different officials like a puppet, Truman could not formulate a firm policy for post V-E Lend-Lease for about two months until mid-July.

From the end of May to the middle of October 1945, negotiations on the 3 (C) Agreement were held again at the suggestion of Harriman. The final cessation of Lend-Lease shipments following the end of the war with Japan was formalized in an appropriate way. Within a few days, the Chairman of the Government Purchasing Commission of the Soviet Union in the United States of America, General Leonid Rudenko, got a note from Crowley who informed him of the general principles of supplies valid till September 20, $1945^{80}$.

An Agreement on the disposition of Lend-Lease supplies in inventory or procurement in the United States was signed on October 15, 1945. According to its terms, the U.S.S.R. was given a loan to pay for previously ordered, but under-supplied before Sep-

76 Truman H. S. Memoirs. In 2 vols. Vol. I. P. 255.

77 Public Opinion, 1935-1946... P. 415.

78 Sherwood R.E. The White House Papers of Harry L.Hopkins. In 2 vols. Vol. II. London, 1949. P. 884-886.

${ }^{79}$ Martel L. Lend-Lease... P. 149; Status of the Soviet Aid Program as of July 31, 1945 // Record of the Foreign Economic Administration. Administrator's File. Box 818.

${ }_{80}$ The Foreign Economic Administrator (Crowley) to the Chairman of the Government Purchasing Commission of the Soviet Union in the U. S. A. (Rudenko). August 27, 1945 // FRUS. 1945. Vol. V. P. 10331034. 
tember 20, 1945 (the official date of the full termination of deliveries in the U.S.S.R.) goods and equipment in the amount of \$240.2 million with a maturity of 30 years and at interest rate of $23 \% 8$ per annum ${ }^{81}$.

At its conclusion, the consent of the U.S. government was obtained to provide the Soviet side with 17 cargo ships to transfer the supplies on the conditions of Lend-Lease, i.e. without payment ${ }^{82}$. As a result, freight savings of about $\$ 6 \mathrm{mln}$, attributable to LendLease, were achieved ${ }^{83}$.

It should be noted that despite the considerable cooling in bilateral relations and the faint interest of the U.S. in the Soviet participation in military operations against Japan, the United States had honorably fulfilled its obligations under Lend-Lease agreements. During the first 9 months of 1945, the Lend-Lease supplies received by the U.S.S.R. amounted to $65 \%$ of the volume of 1944 ( $\$ 1.7$ bln versus $\$ 2.6 \mathrm{bln}$ ), whereas supplies to the United Kingdom for January-September 1945 amounted to only $47 \%$ of the same period in 1944 ( $\$ 1.88$ bln against $\$ 4.01 \mathrm{bln})^{84}$.

Dwelling on the political role of Lend-Lease in Soviet-American relations, it should, first of all, be stressed that the formal cessation of Lend-Lease deliveries in May 1945 was not "a complete surprise" for the Soviet leadership as it sounded in the answering note submitted by the Soviet chargé d'affaires Nikolay Novikov on May $16^{85}$, and as it is commonly believed in the national historiography ${ }^{86}$. This can be proved by documentary evidence.

First, on January 7, 1944, in a letter to the Secretary of State Hull, Harriman refers to his conversation with the People's Commissar for Foreign Affairs, Viacheslav Molotov, held on December 31, 1943. During this conversation, Molotov asked Harriman about the prospects for post-war U.S. assistance to the Soviet Union. The latter warned him about the legal limitations of Lend-Lease and suggested that the "possibility of the extension by an agency of the United States Government to the Soviet Government of a credit for the purchase in the United States of equipment and supplies for reconstruction" be discussed. He recommended Molotov to forward the list of the needed supplies to Washington at the earliest possible moment. Harriman further relates that Molotov "showed the keenest interest and by his questions and comments indicated that he understood and approved (italics added. - K. M.) the approach I had outlined" ${ }^{87}$. The collection of documents on the U.S. foreign policy, in which this letter was published, was released in 1944, making any falsification of facts in favor of the United States absolutely impossible.

Secondly, in the middle of March 1944, Harriman met with Mikoyan, the People's Commissar for Foreign Trade, where he presented all the proposals of the U.S. administration on the organization of post-war supplies to the U.S.S. R. ${ }^{88}$ In a message to Hull

${ }^{81}$ Butenina N. V. Lend-Liz: sdelka veka. P. 165.

82 Rossiiskii gosudarstvennyi arkhiv ekonomiki (RGAE). F. 413. Op. 12. D. 9870. L. 56-59.

83 Ibid.

84 Ibid. L. 5, 6.

85 AVPRF. F. 6. P. 45. D.702. L.2.

${ }^{86}$ Pechatnov V.O. Ot soyuza - k vrazhde (sovetsko-amerikanskie otnosheniia v 1945-1946 gg.) // Kholodnaya voŭna: istoricheskaia retrospektiva / eds N. I. Egorova, A. O. Chubarjan. Moscow, 2003. P. 35.

87 The Ambassador in the Soviet Union (Harriman) to the Secretary of State. January 7, 1944 // FRUS. 1944. Vol. IV. P. 1032-1033.

${ }^{88}$ The Ambassador in the Soviet Union (Harriman) to the Secretary of State. March 17, 1944 // Ibid. P. 1063-1065. 
dated March 23, 1944, Harriman communicated that "he discussed the idea expressed in article 2 of proposed agreement" which mentioned termination of Lend-Lease supplies after the determination of the end of hostilities by the president of the United States ${ }^{89}$.

It is extremely important to note that in a conversation with Harriman on June 11, 1945, Mikoyan confessed to him that he knew about the alleged cessation of supplies after the end of hostilities in Europe, but did not expect it to happen so suddenly. In addition, Mikoyan recalled that the proposal to begin negotiations on the Fifth Protocol made by the American side in early 1945 made him think that the Americans had decided to change the terms of the Lend-Lease program ${ }^{90}$.

Thirdly, the Foreign Policy Archive of the Russian Federation holds an aide-memoir handed by the U.S. Assistant Secretary of State, Dean Acheson, to the Soviet ambassador to the United States, Andrey Gromyko, on May 24, 1944. It suggests discussing a draft of the proposed agreement supplementing the Preliminary Agreement of Mutual Aid between the two governments, dated June 11, 1942. This part of the document reads: "The subject matter of the proposed agreement is a plan for the continuance of an uninterrupted flow of Lend-Lease supplies to the Soviet Union during hostilities against our common enemy and for the orderly liquidation (italics added. - K.M.) of Lend-Lease supply arrangements upon the termination of hostilities". This aide-memoir also suggests continuation of supplies on certain terms of repayment (italics added. - K. M.). Article 2 of the proposed agreement reads:

"Within such periods as may be authorized by law, the Government of the United States undertakes to transfer to the Government of the Union of Soviet Socialist Republics, after a determination by the President of the United States that active military operations against the common enemy have ceased, and the Government of the Union of Soviet Socialist Republics undertakes to accept, those supplies... which the Government of the United States shall have agreed to make available in order to provide war aid to the Government of the Union of Soviet Socialist Republics and, prior to the said determination of the President, shall have contracted for or shall have an inventory.

$<\ldots>$ The Government of the Union of Soviet Socialist Republics undertakes to pay the Government of the United States in dollars the cost of the supplies transferred under the provisions of this Article ${ }^{391}$.

It should be especially noted that this document was drawn up a month after the signing of the Fourth Protocol on Lend-Lease supplies, so that it could not be attributed to it in any way, and in view of the obvious unconditional victory of the Allies in the war against the Axis.

In addition, there is evidence that during 1944, Mikhail Stepanov, the Deputy People's Commissar for Foreign Affairs, actively participated in the Soviet-American negotiations on the development of principles for the organization of post-war supplies of American

89 The Ambassador in the Soviet Union (Harriman) to the Secretary of State. March 23, 1944 // Ibid. P. 1069-1071.

${ }_{90}$ Memorandum of Conversation, by the First Secretary of Embassy in the Soviet Union (Page). June 11, 1945 // FRUS. 1945. Vol. V. P. 1019-1020.

91 Aide-Memoir from Acheson to Gromyko transferred on May 24, 1944 // AVPRF. F. 6. Op. 6. P. 46. D. 624. L. $13,16$. 
equipment and materials in the U.S.S.R. and was also kept thoroughly advised of the matter ${ }^{92}$.

The Soviet and American sides didn't see eye to eye on the events that immediately followed the publication of the May 12 note. The U.S.S.R. Embassy in Washington learned of the termination of deliveries from its sales representatives in the port even before receiving an official message from the State Department. Novikov immediately called Grew, who stated that he had no knowledge of ships being turned around and advised the former to address the same question to Assistant Secretary Clayton ${ }^{93}$. According to the Chairman of the Government Purchasing Commission of the Soviet Union in the U.S.A. General Rudenko, "as a result of our measures and negotiations with representatives of U.S. government bodies, these decisions were canceled the same day, on May 12, and the Americans were instructed that steamships being loaded in the East Coast ports should continue the loading, and the ships on the way must proceed to the ports of the U.S.S.R." 94

It is mistakenly believed in the national historiography that the first talks on the further settlement of Lend-Lease after the conclusion of 1945 agreement between the U.S.S.R. and the U.S.A. began in $1947^{95}$. In fact, this question had never come off the agenda of the Soviet-American negotiations. On January 4, 1946 Willard Thorp, Deputy to the Assistant Secretary of State for the Economic Affairs reminded Leonid Rudenko that the American side was still waiting for an inventory of Lend-Lease supplies in the possession of the U.S.S.R. ${ }^{96}$

As in the case of a number of other important issues of bilateral economic cooperation, which called for Moscow's rapid reaction in late 1945, the decision to grant such an inventory was delayed. It might be explained by at least two reasons. First, according to the testimony of a number of Soviet officials and Stalin's daughter Svetlana Allilueva, in October-December 1945, Joseph Stalin suffered a serious illness - a stroke or a TIA $^{97}$. He recuperated from the consequences of this illness at his dacha in Abkhazia until mid-December 1945, and therefore could not be fully aware of the developments of the international situation. We also believe that the members of the Politburo informed him of a limited number of burning issues, such as the settlement of the Japanese and Iranian problems, the situation around Korea, etc.

Secondly, the Soviet leadership did not want to take any fundamental steps regarding the international economic cooperation until the terms of the post-war loan were agreed with the American side. In this regard, the financial agreement between the United States and Great Britain on December 6, 1945, became "fatal" for Moscow. Great Britain managed to profitably "sell" cooperation with the U.S.A. within the framework of the Bret-

\footnotetext{
92 Memorandum of Conversation by the First Secretary of Embassy in the Soviet Union (Page). June 11, 1945 // FRUS. 1945. Vol. V. P. 1019-1020.

93 Herring G. C., Jr. Aid to Russia... P. 205.

$94 \mathrm{Iz}$ otcheta predsedatelia Pravitel'stvennoi zakupochnoй komissii v SShA general-leitenanta L. G. Rudenko o rabote komissii za 1945 g. 5 marta 1946 g. // RGAE. F. 413. Op. 12. D. 9870. L. 3-10.

95 Korotkov G. I. Lend-liz: mify i real'nost' // SShA: ekonomika, politika, ideologiia. 1985. N 6. P. 52.

96 Mr. Willard L. Thorp, Deputy to the Assistant Secretary of State for Economic Affairs, to the Chairman of the Government Purchasing Commission of the Soviet Union in the U.S. A. (Rudenko). January 4, 1946 // FRUS. 1946. Vol. VI. P. 818-819.

97 Allilueva S. Dvadtsat' pisem k drugu. Moscow, 1989. P. 20-21.
} 
ton Woods institutions and with respect to the principles of drafting the Charter of the International Trade Organization ${ }^{98}$. The Soviet government mistakenly believed that its support would be of a similar fundamental nature for Washington, and, for its part, was also preparing to sell it profitably ${ }^{99}$. Meanwhile, by the end of 1945, the U.S. leadership not only decided to categorically change the approach to negotiations with the U.S.S.R., abandoning any concessions ${ }^{100}$, but also began to develop a rather indifferent attitude to the prospects of participation or non-participation of the Soviet Union in the creation of post-war trade and economic institutions. In addition, back in January 1945, when the question of granting Moscow a large credit was actively and sympathetically discussed in Washington, a Chief of the Financial and Monetary Affairs Department, Emilio Collado, informed the State Department that according to their estimations, Russia could reattain the pre-war level of capital investment by 1948 with no foreign loans and only limited use of its gold reserves and production, plus reparations deliveries ${ }^{101}$. Thus, seeing no urgent need to help the Soviet economy, which in a few years was to return to the pre-war level, the U.S. administration did not consider it necessary to fight the Congress ${ }^{102}$ for granting the U.S.S.R. a loan on more favorable terms than those that were offered to other Allies ${ }^{103}$. These sentiments were further strengthened with Truman coming to power: he even preferred to "forget" about the application for a loan formally submitted by the Soviet Union ${ }^{104}$.

Finally, another factor that could also play a role in the inability / unwillingness of the Soviet side to quickly satisfy some of the U.S. requests was the false sense of its moral leadership in the world developed by Moscow in 1944-1945 on account of the huge price that the U.S.S.R. paid for the victory. It was this feeling that could lead to a deep conviction that there was no reason to hurry with resolving issues that the Soviet leadership did not regard as critically important. Moscow officials mistakenly believed that no important decisions would ever be made without the Soviet Union ${ }^{105}$. As for the inventory of LendLease supplies, its compilation, in the opinion of the Soviet government, did not belong to a number of those foreign policy tasks that required an immediate solution.

The United States treated it quite differently. In a note sent by U.S. Secretary of State James Byrnes to the Soviet chargé d'affaires Fyodor Orekhov on February 21, 1946, the settlement of Lend-Lease was linked to the solution of other fundamentally important problems of a bilateral and multilateral nature. Leaving the detailed considerations of the

98 Financial Agreement between the Government of the United States and the United Kingdom dated 6th December, 1945. London, 1945.

99 This supposition is proved by: Herring G. C., Jr. Aid to Russia... P. 250.

100 It is more than appropriate here to recall a widely known comment made by Truman in early January, 1946: "I'm tired of babying the Soviets" // The Truman Administration. A Documentary History / eds B. J. Bernstein, A. J. Matusow. New York, 1966. P. 197-198.

101 Memorandum by the Chief of the Division of Financial and Monetary Affairs (Collado). January 4, 1945 // FRUS. 1945. Vol. V. P. 939.

102 See: Memorandum by Mr. George F. Luthringer of the Office of Financial and Development Policy to the Assistant Secretary of State for Economic Affairs (Clayton). May 23, 1946 // FRUS. 1946. Vol. VI. P. 842-843.

103 Financial Agreement between the Government of the United States and the United Kingdom. P. 2.

104 See: Herring G. C., Jr. Aid to Russia... P. 255-256.

105 In particular, the directions for the Soviet delegation which was supposed to participate in the ITO Charter talks hade been finalized by the end of summer 1946, when the U.S. A. was preoccupied with a broad anti-Soviet campaign. See: Directions for the loan and other economic negotiations with the U.S.A. // Rossijski gosudarstvennij arkhiv social'noj i politicheskoj istorii (RGASPI), F. 84. Op. 1. D. 28. 
reasons for such phrasing of this note on the sidelines of this article ${ }^{106}$, we should note that the settlement of Lend-Lease was tied, in particular, to the questions of the participation of the Soviet Union in the international financial, economic and trade bodies created in $1945-1946^{107}$. The Soviet leadership understandably reacted to Byrnes's note extremely negatively. Moscow was ready to discuss the Lend-Lease settlement only in conjunction with those issues that it considered to be directly related to it, i.e. provision of credit by the United States Government to the Government of the Union of Soviet Socialist Republics, conclusion of a treaty of friendship, commerce and navigation between the Union of Soviet Socialist Republics and the United States of America and methods for giving effect to the terms of article VII of the Soviet Master Lend-Lease Agreement of June 11, 1942, i.e. participation in the talks on the Charter of International Trade Organization ${ }^{108}$.

On March 18, 1946 another note was sent to the Soviet Ambassador Novikov, in which it was offered to the Soviet Union in a very strict form either to return or to purchase 96 Liberty ships, tankers and cargo vessels that had been "remaining in the custody of the Soviet Union"109.

The exchange of notes on this issue continued against the backdrop of a sluggish bargaining about the list of issues that the Soviet government was ready to discuss in conjunction with the problem of Lend-Lease settlement.

On June 13, 1946, the U.S. government designated the repayment of Lend-Lease (that is, payment for all equipment and transport that remained in the country by September 2, 1945 and not returned to the U.S. A.) as an indispensable condition for obtaining new loans for all Lend-Lease recipients ${ }^{110}$. This was followed by long and difficult negotiations between the United States and the U.S. S. R. on methods for estimating amortization and, accordingly, the total amount of Soviet debt.

No progress in these negotiations had been achieved until early September 1946. It made the State Department offer Moscow separate negotiations on the terms of the Lend-Lease redemption to get at least some result ${ }^{111}$. The corresponding note was sent by Clayton to Orekhov on September 14, 1946 ${ }^{112}$. In addition, the U.S. officials saw these negotiations as a means to return three icebreakers delivered to the U.S.S.R. on terms of Lend-Lease and subject to return to the United States after the end of hostilities, but still remaining in the U.S.S.R. at the time ${ }^{113}$.

This note remained unanswered, and on October 31, 1946, the State Department sent to the Soviet embassy in the United States an aide-memoir, repeating its text word-for-

106 Minkova K. $\mathrm{V}$. The Economic Roots of the Cold War: The IMF, ITO and Other Economic Issues in Post-War Soviet-American Relations // Journal of Global Initiatives. 2017. Vol. XIII, N 1. P.18-31.

107 The Secretary of State to the Chargé of the Soviet Union (Orekhov). February 21, 1946 // FRUS. 1946. Vol. VI. P. 828-829.

108 The Chargé of the Soviet Union (Novikov) to the Secretary of State. March 15, 1946 // Ibid. P. 829 830.

109 The Secretary of State to the Chargé of the Soviet Union (Novikov). March 18, 1946 // Ibid. P. 830 831.

110 Butenina N. V. Lend-Liz: sdelka veka. P. 167.

111 Memorandum by the Acting Chief of the Division of Lend-Lease and Surplus War Property Affairs (Matlock) to the Director of the Office of Financial and Development Policy (Ness). September 3, 1946 // FRUS. 1946. Vol. VI. P. 853.

112 The Acting Secretary of State to the Chargé of the Soviet Union (Orekhov). September 14, 1946 // Ibid. P. 854-855.

113 The Secretary of State to the Chargé of the Soviet Union (Orekhov). July 26, 1946 // Ibid. P. 852. 
word $^{114}$. On December 3, Clayton informed Byrnes that the American proposals for the immediate initiation of Lend-Lease settlement remained unanswered ${ }^{115}$. The situation did not change by the end of December, as Byrnes communicated to the U.S. Ambassador to the U.S.S.R. William B. Smith ${ }^{116}$. It seems that apart from purely political considerations, Moscow had two other reasons to persistently ignore Washington's proposals. First, at the end of 1946, the Soviet and American sides still did not see eye to eye on the sum that the Soviet Union was supposed to pay the United States. The Soviet leadership probably needed time to collect relevant data and challenge the U.S. claims. In addition, by the end of the summer of 1946 directives were prepared for the Soviet delegation with reference to the February 21 note on the comprehensive solution of economic problems between the parties ${ }^{117}$. In these directives, the issue of getting the loan occupies the top position while other questions are "tied" to it, ranked in priority order. Thus, the detailed instructions on settlement for supplies and redemption of American ships contained several options, depending on the outcome of the loan negotiations. The second priority, a treaty of friendship and navigation, was to be concluded in the case of a favorable outcome etc. Therefore, the directives represented a certain algorithm with a sequence of iterations which could not be violated. Since the bureaucratic machine that developed such directions was extremely slow during the period under review, a rapid adaptation to the new situation and the prompt resolution of a new task was completely unimaginable.

Only on April 5, 1947, an urgent secret telegram from Smith notified Byrnes of the readiness of the Soviet side to immediately begin negotiations on settlement of accounts. On April 15, during a personal meeting with Stalin in Moscow, the new U.S. Secretary of State George Marshall asked him about the reasons for the reluctance to begin talks on Lend-Lease. Stalin referred to occasional sloppiness of the Soviet government coming from its daily routine of solving more important issues arising from the great losses in the war. Immediately after that, Stalin raised the question of a loan, to which Moscow didn't receive any response from Washington for more than two years ${ }^{118}$. That meeting did not result in anything more constructive than the exchange of mutual accusations of negligence.

The day before the conversation between Marshall and Stalin, the Central Committee of the All-Union Communist Party of the Bolsheviks approved of the Directives on the settlement of Lend-Lease ${ }^{119}$. They implied payments to the American side for goods, materials and equipment supplied to the U.S.S. R. with very substantial amortization. The talks began on April 30, 1947, in Washington. The Soviet side was represented by the Soviet ambassador in the U.S. Nikolay Novikov and the head of the Department of the Ministry of Foreign Affairs, Amazasp Arutiunian ${ }^{120}$. By mid-July, no tangible progress had been achieved at the talks.

114 The Department of State to the Embassy of the Soviet Union. October 31, 1946 // Ibid. P. 855-856.

115 Memorandum by the Under-Secretary of State for Economic Affairs (Clayton) to the Secretary of State. December 3, 1946 // Ibid. P. 858-859.

116 The Secretary of State to the Ambassador in the Soviet Union. December 23, 1946 // Ibid. P. 860-861.

117 Directions for the loan and other economic negotiations with the U.S. A // RGASPI. F. 84. Op. 1. D. 28.

118 Memorandum of Conversation between Stalin and Marshall. April 15, 1947 // FRUS, 1947. Vol. II. P. 341.

119 Postanovlenie TsK VKP(b) ob utverzhdenii prilagaemogo proekta otveta pravitel'stvu SShA po voprosu o lend-lize. 18 noiabria 1947 // RGASPI. F. 17. Op. 166. D. 788. L. 68; D. 791. L. 76-79.

${ }^{120}$ United States Side Minutes of First Combined Meeting on Lend-Lease Settlement Negotiations. April 30, 1947 // FRUS. 1947. Vol. IV. P. 680-683. 
On June 25, 1947, a list of all American proposals for Lend-Lease settlement was sent to Novikov ${ }^{121}$. It is noteworthy that this list contained neither any indication of the exact amount that the Soviet Union was supposed to pay to the U.S., nor the methodology for calculating it.

The answer to these proposals was approved by the decision of the Central Committee of the All-Union Communist Party of the Bolsheviks as late as on November 18, $1947^{122}$. However, since it also lacked any specific figures, by late 1947 the Lend-Lease negotiations still remained far from completion.

In conclusion, it is to be stressed again that the May 12, 1945 note on the cessation of Lend-Lease supplies to the U.S.S.R. was not directed solely against the Soviet Union and did not appear completely unexpected for the Soviet leadership. At the same time, the U.S. administration (not only Harry Truman and his team by their actions, but also F.D. Roosevelt and his associates with their inaction) provoked the first serious conflict with Moscow during the war period. This conflict has undoubtedly left its imprint on all the subsequent negotiations between the United States and the Soviet Union. In addition, the national historiography makes virtually no connection between the settlement of Lend-Lease, the provision of the U.S. loan to the U.S.S.R., and the participation of the Soviet Union in the development and activity of post-war trade and economic institutions. Meanwhile, this connection is more important as it unquestionably determined those events in the Soviet-American economic sphere that eventually led to the beginning of the "Cold war".

\section{References}

Butenina N. V. Lend-Liz: sdelka veka. Moscow, GU VShE Press, 2004, 312 p. (In Russian)

Chuzavkov L. M. Voenno-ekonomicheskoe sotrudnichestvo SSSR s SShA $i$ Velikobritaniei v gody II mirovol voiny. Moscow, Mezhdunarodnye otnosheniia Publ., 1972, 25 p. (In Russian)

Dalin S. Voenno-gosudarstvennyı monopolisticheskǐ kapitalizm v SShA. Moscow, AN SSR Press, 1961, 350 p. (In Russian)

Dawson R. H. The Decision to Aid Russia, 1941: Foreign Policy and Domestic Politics. Chapel Hill, University of North Carolina Press, 1959, 315 p.

Dunaeva N. Lend-liz: fakty i vymysly. Voenno-istoricheskil zhurnal, 1977, no. 3, pp. 102-106. (In Russian)

Golovatina P. M., Kamynin V.D. Anglo-amerikanskaia pomoshch' Sovetskomu Soyuzu po lend-lizu: vzgliad zarubezhnoŭ istoriografii. Ural'skii vestnik mezhdunarodnykh issledovaniŭ, 2005, iss. IV, pp. 19-29. (In Russian)

Herring G. C. Aid to Russia, 1941-1946. New York, Columbia University Press, 1973, 365 p.

Herring G. C. Experiment in Foreign Aid: Lend-Lease, 1941-1945. University of Virginia Press, 1965, 487 p.

Herring G. C. Lend-Lease to Russia and the Origins of the Cold War, 1944-1945. The Journal of American History, 1969, vol. 56, no. 1, pp. 93-114.

Komarkov A. Yu. Lend-liz dlia SSSR v pervyĭ god Velikoĭ Otechestvennoŭ: osobennosti, problemy, itogi. Obshchestvo, sreda, razvitie (Terra Humana), 2012, no. 1, pp. 74-78. (In Russian)

Korotkov G. I. Lend-liz: mify i real'nost'. SShA: ekonomika, politika, ideologiia, 1985, no. 6, pp. 47-53. (In Russian)

Krasnov V. N., Krasnov I. V. Lend-liz dlya SSSR, 1941-1945. Moscow, Nauka Publ., 2008, 248 p. (In Russian)

Kravtsova Zh. V., Buriak I. I. Voenno-ekonomicheskoe sotrudnichestvo stran antigitlerovskoĭ koalitsii v 19411945 gg.: istoriia i sovremennye otsenki. Krasnodar, KubGTU Press, 2015, 59 p. (In Russian)

Langer W. L., Gleason S. E. The Undeclared War, 1940-1941. New York, Harper \& Brothers, 1953, 963 p.

Lend-Liz i Rossiia. Ed. by M. N. Suprun. Arkhangelsk, Pravda Severa Publ., 2006, 271 p. (In Russian)

121 Outline of the Main Points of Settlement Proposed by the United States Side. June 25, 1947 // FRUS. 1947. Vol. II. P. 696-702.

122 RGASPI. F. 17. Op. 166. D. 791. L. 76-79. 
Lugovskoŭ S., Remizova S. Lend-liz: istoriia i sovremennost'. E. Stettinius, Zagadki lend-liza. Moscow, Veche Publ., 2000, pp. 349-397. (In Russian)

Martel L. Lend-Lease, Loans and the Coming of the Cold War: A Study of the Implementation of Foreign Policy. Boulder (Col.), Westview Press, 1979, 304 p.

Minkova K. V. The Economic Roots of the Cold War: The IMF, ITO and Other Economic Issues in Post-War Soviet-American Relations. Journal of Global Initiatives, 2017, vol. XII, no. 1, pp. 18-31.

Olson L. Those Angry Days: Roosevelt, Lindbergh, and America's Fight Over World War II, 1939-1941. New York, Random House Trade Paperbacks, 2014, 548 p.

Pechatnov V. O. Ot soyuza - k vrazhde (sovetsko-amerikanskie otnosheniia v 1945-1946 gg.). Kholodnaya voina: istoricheskaia retrospektiva. Eds N.I.Egorova, A. O.Chubarjan. Moscow, Olma-Press Publ., 2003, pp. 21-64. (In Russian)

Pozdeeva L. V. Lend-liz dlya SSSR: diskussiia prodolzhaetsia. Vtoraia mirovaia voina. Aktualnye problemy. Ed. by O. A. Rzeshevskii. Moscow, Nauka Publ., 1995, pp. 324-339. (In Russian)

Sirgiovanni G. An Undercurrent of Suspicion: Anti-communism in America during World War II. New Brunswick, Transaction Publishers, 1990, 209 p.

Sokolov B. V. Diplomatiia i lend-liz. E. Stettinius, Zagadki lend-liza. Moscow, Veche Publ., 2000, pp. 333348. (In Russian)

Sokolov B. V. Rol' lend-liza v Velikoi Otechestvennoi voine 1941-1945 gg. E. Stettinius, Zagadki lend-liza. Moscow, Veche Publ., 2000, pp. 305-332. (In Russian)

Stepanova O.L. «Kholodnaia voina»: istoricheskaia retrospektiva. Moscow, Mezhdunarodnye otnosheniia Publ., 1982, 192 p. (In Russian)

Suprun M.N. Prodovol'stvennye postavki v SSSR po lend-lizu v gody II mirovoi voiny. Otechestvennaia istoriia, 1996, no. 3, pp. 46-54. (In Russian)

Received: 16.01 .2018

Accepted: 30.03 .2018 